\title{
Genetic signature of the natural gene pool of Tilia cordata Mill. in Lithuania: compound evolutionary and anthropogenic effects
}

\author{
Darius Danusevičius ${ }^{1}$, Ruta Kembryte ${ }^{1}$, Jurata Buchovska ${ }^{2}$, Virgilijus Baliuckas ${ }^{2}$, and \\ Darius Kavaliauskas ${ }^{3}$
}

${ }^{1}$ Vytautas Magnus University

${ }^{2}$ Lithuanian Research Centre for Agriculture and Forestry

${ }^{3}$ Bawarian Office for Forest Genetics (AWG)

October 9, 2020

\begin{abstract}
Tilia cordata Mill. is a valuable tree species enriching the ecological values of the coniferous dominated boreal forests in northerly Europe. Following the historical decline, spreading of Tilia sp. is challenged by the elevated inbreeding and habitat fragmentation. We aimed to identify the main factors affecting the genetic potential of Tilia cordata for natural expansion by studying the geographical distribution of genetic diversity of Tilia cordata in semi-boreal forests of Lithuania. We used 14 genomic microsatellite markers to genotype 543 individuals from 23 wild growing populations of Tilia cordata in Lithuania. We found that Tilia cordata retained high levels of genetic diversity (population Fis $=0$ to 0.15 , Ho $=0.53$ to 0.69 , He $=0.56$ to 0.75). AMOVA, Bayesian clustering and Monmonier's barrier detection indicate weak but significant differentiation among the populations $\left(\mathrm{Fst}=0.037^{* * *}\right.$ ) into geographically interpretable clusters of (a) western Lithuania with high genetic heterogeneity but low genetic diversity, bottleneck effects, (b) peaking values of genetic diversity of Tilia cordata on rich and most soils of midland lowland, and (c) the most differentiated populations on poor soils of the coolest north-eastern highland possessing the highest rare alle frequency but elevated inbreeding and bottleneck effects, presumably, due to sub-structuring. We conclude that the genepool of Tilia cordata in Lithuania contains (a) the autochthonous populations of high genetic diversity representing the pre-historical genepools, that can be promoted, and (b) the escapes from urban sources of low diversity, that must be contained.
\end{abstract}

\section{Hosted file}

paper Tilia_OK.odt available at https://authorea.com/users/365660/articles/485678genetic-signature-of-the-natural-gene-pool-of-tilia-cordata-mill-in-lithuania-compoundevolutionary-and-anthropogenic-effects 